\title{
The Use of Task-Based Learning to Enhance Speaking Skill of Senior High School Students
}

\author{
Afria Nita $^{1}$, Yenni Rozimela ${ }^{2}$, and Ratmanida ${ }^{3}$ \\ ${ }^{1}$ Universitas Negeri Padang, Padang, Indonesia afria.nita89@gmail.com \\ ${ }^{2}$ Universitas Negeri Padang, Padang, Indonesia yennirozi@gmail.com \\ ${ }^{3}$ Universitas Negeri Padang, Padang, Indonesia ratmanida@gmail.com
}

\begin{abstract}
This research was aimed at investigating the use of Task-Based Learning in enhancing speaking skill of senior high school students. This research was a quantitative research which used quasi-experimental design. This research assigned two classes; experimental and control class which each class consisted of 36 students. The two classes were given different treatment; Task-Based Learning was treated in Experimental class and Conventional Teaching was treated in Control Class. Speaking test was used to obtain speaking score. T-test formula was used to analyze the data. The result showed that there was a significant influence of Task-Based Learning on students' speaking skill. It was proven by the value of $\mathrm{t}_{\text {observed }}$ was 5.270 which was higher than the value of table 1.669 . Thus, it indicated that the students who were taught by Task-Based Learning had better speaking ability than those who were taught by Conventional Teaching.
\end{abstract}

\section{Keywords: Task-Based Learning, Speaking Skill}

\section{INTRODUCTION}

An ability to speak is very needed to acquire by everyone. One's ability in a language is often seen from their ability to produce that language in expressing opinions, thoughts and feelings (Malihah, 2010). In addition, speaking skill is often used as a parameter for learners' success on English learning (Richards, 2008). In other words, the students' success on learning English will be seen from their ability to speak using English. For this reason, mastering speaking skill is very important to acquire by the English language learners.

Speaking is a productive skill which is used to convey meaning (Cameron,2001:40) and it consists of producing systematic verbal utterances (Nunan,2003 :48). The purpose of teaching speaking is to get competence on grammar, sociolinguistic, discourse and strategic skill (Brown,2007). Based on high school current Indonesia curriculum (curriculum 2013), the purpose of teaching speaking is to get students be able to express their ideas, opinions or thoughts through spoken and written language. They are not only demanded to master interpersonal and transactional communication, but also they should be able to produce spoken and written language about several genre of texts, such as; descriptive, recount, narrative texts, etc. Thus, the role of speaking is not only for conversation about daily activities, but also for telling their knowledge and opinion about several informations of texts.

However, mastering speaking skill is often difficult for some reasons. Ur (1996) states some students' problems in speaking such as; worry to make mistake, fearful of criticism, shy to speak and lack of vocabulary. In recent studies, Malihah (2010) found that the problem in speaking is that the students need courage and preparation before producing the spoken language. Also, Alexsandrzak (2011) found the difficulties of speaking is caused by the lack of speaking practice beyond classroom. In brief, the students' problem is not only related to their psychological factors, but also related to the teachers' competence in creating classroom learning that provide speaking practices.

Toward those problems above, an appropriate method is very essential in teaching speaking. A good and appropriate method can help the students to get success in learning process (Zhou, 2016). In teaching speaking, practice is very important. As for this case, Task-Based Learning is suitable method to be implemented since this method provides speaking practices for the students. It emphasizes the students to use English in class and discuss and negotiate their arguments during task accomplishment. Therefore, the students can practice the target language maximally through the task-based activities.

Task-Based Language Teaching or Task-Based Learning (TBL) is a method where the students learn language through some tasks (Richards and Rodgers, 2001). Task itself can provide opportunities for students to improve and develop their speaking skill. Willis and Willis (2007) propose some criteria of communicative tasks which make them different with common classroom activities. The tasks can be said communicative if they are engaging. It also should concern to convey message of the language hence it can improve speaking as the outcome. 
Then, the task is successful if the outcome is gained. It also should be done in one meeting. Last, it relates to students' real life.

In Task-based Learning, there are many tasks that had been used by experts. As Prabhu (1987 :46) divided task into; information gap task, reasoning gap task, and opinion gap task. Willis (1996:26) divided task into; listing, ordering and sorting, comparing, problem-solving, sharing personal experiences and creative tasks. Finally, Nunan (2004:1) offers two task types ; real world and pedagogical tasks. Also, Nunan (2004 :60) involves diagramming as the task that can be used in teaching speaking. From all task types, the researcher will use some tasks that are appropriate to the students' needs and ability.

In Task-Based Learning, there are three framework (Willis, 1996). It involves pre-task stage, task cycle stage and language focus stage. Pre-task involves topic introduction and task introduction. Topic introduction includes brainstorming and task introduction includes demonstration of the task. Task-cycle phase consists of tasks, planning activity, reporting or presenting. In doing task, students are given task in pair or group. In the planning activity, students plan and rehearse the task report within group. In reporting activity, students perform the task report. Last stage is language focus which divides into language analysis and practice. Language analysis aimed to get students to identify the language features. In language analysis, the teacher can set some languagefocused task to identify some language features, for example; finding words or phrases related to the topic, or finding the verb in simple past form. Then, in language practice, the students practice the language features that had been identified either in oral or written language practices.

In this case, Task-Based Learning is assumed as good method to see the improvement of students' speaking since the activities includes communicative activities. The students will engaged to speak through accomplishing task that related to students' real life (Richards and Rodgers, 2001). In support, there are also several studies that had been conducted by previous researchers that related to influence of Task-Based Learning towards speaking. Mostly, Task-Based Learning gave significant effect towards speaking improvement. Task-Based Learning give chances for students to practice speaking with partners, thus they have more confidence and less anxiety to speak (Ho \& Long, 2014; Anjum,et.al, 2019). Additionally, Task-Based Learning could increased students' communicative competence (Carolina,2016) and speaking fluency since their grammar was not corrected explicitly and they would be more active to speak when they were provided the authentic or real world tasks (Albino,2017).

In Indonesia, there is limited research that investigated the use of a method on improvement of speaking on genre or text. Most of the previous studies had conducted the study of Task-Based Learning and Speaking towards transactional conversation (Mudra, 2016; Albino,2017). Thus, it is important to do research which focus on investigating the use of Task-Based Learning in enhancing speaking skill of genre or texts.

\section{METHOD}

This research was quasi-experiment. Research population was ten grade students of MIPA classes at SMAN 3 Padang. The number of population was eight classes which consisted of 287 students. Two classes were selected randomly as the research sample; experimental and control. The experiment was treated by Task-Based Learning and control was treated by Conventional Teaching.

The research instrument was speaking test which was given after treatment. The speaking test consisted of two kinds; monologue and dialogue. Speaking ability of Historical Recount was assessed thorugh monologue and Narrative Text was assessed through dialogue. For monologue test, the students were given several topics of Historical Recount that must be presented in front of the class. They were free to choose one topic that they had already known. For dialogue test, the students were asked to create a dialogue based on one topic of Narrative Text that they chose among several topics provided.

This research was conducted during 8 weeks. During this period of time, the experimental class was treated by Task-Based Language Teaching and Control Class was taught by Conventional Teaching. After treatment, the researcher gave post test which consisted of monologue and dialogue test. In scoring, the researcher used scoring rubrics which was adapted from Brown (2001) which includes grammar, vocabulary, content or comprehension, fluency and pronunciation. In analyzing the data of speaking test, the researcher used SPSS 18 For Windows. In this research, normality and homogeneity testing were tested by Shapiro Wilk Test. To test the hypothesis, the researcher used independent sample t-test with significance alpha 0.05 .

Content validity and inter-rater reliability were used to to measure test validity and reliability. Content validity was checked through the appropriateness between test and syllabus, then consulted and validated by the validator who was expert on English. Next, Inter-rater reliability was used to measure test reliability. Two scorers were used to calculate the students' score. The scorers were researcher and English teacher. Final score of speaking test was accumulated from the total score of two scorers.

In this research, there were two hypotheses including null hypothesis (H0) and alternative hypothesis (Ha). The hypotheses can be seen as follow:

H0 : Task-Based Learning does not give more significant influence on students' speaking skill than Conventional Teaching

Ha : Task-Based Learning gives more significant influence on students' speaking skill than Conventional Teaching

The statistical hypothesis could be written as follow :

$\mathrm{H} 0: \mu \mathrm{A} 1=\mu \mathrm{A} 2$

$\mathrm{Ha}: \mu \mathrm{A} 1 \neq \mu \mathrm{A} 2$ 
Note :

$$
\begin{array}{ll}
\mu & : \text { Students' speaking skill } \\
\text { A1 } & \text { : Task-Based Learning } \\
\text { A2 } & \text { : Conventional Teaching }
\end{array}
$$

Independent sample t-test was used to test research hypothesis. The value of $t_{\text {observed }}$ was compared to the value of $t_{\text {table. }}$. Ha is accepted if the value of $t_{\text {observed }}$ is higher than $t_{\text {table }}$ and $\mathrm{Ha}$ is rejected if the value of $\mathrm{t}_{\mathrm{observed}}$ is lower than $t_{\text {table }}$

\section{RESULTS AND DISCUSSION}

After analyzing the speaking data, it was gained, the students who were taught by Task-Based Learning had better speaking than those who were taught by Conventional Teaching. Thus, Task-Based Learning gave influence in enhancing speaking. The description of data is described as follow :

Table 1. The Summary of Speaking Score in Experiment and Control Class

\begin{tabular}{|c|c|c|c|c|c|c|c|}
\hline Class & $\mathbf{N}$ & $\begin{array}{c}\text { Me } \\
\text { an }\end{array}$ & $\begin{array}{c}\mathbf{M a} \\
\mathbf{x}\end{array}$ & $\begin{array}{c}\mathbf{M i} \\
\mathbf{n}\end{array}$ & $\mathbf{S D}$ & $\begin{array}{c}\text { Varia } \\
\text { nce }\end{array}$ & $\begin{array}{c}\text { Su } \\
\mathbf{m}\end{array}$ \\
\hline $\begin{array}{c}\text { Experim } \\
\text { ent }\end{array}$ & $\begin{array}{c}3 \\
6\end{array}$ & $\begin{array}{c}86.9 \\
4\end{array}$ & 94 & 80 & $\begin{array}{c}3.3 \\
9\end{array}$ & 11.54 & $\begin{array}{c}312 \\
6\end{array}$ \\
\hline Control & $\begin{array}{c}3 \\
6\end{array}$ & $\begin{array}{c}81.7 \\
2\end{array}$ & 92 & 74 & $\begin{array}{c}4.8 \\
7\end{array}$ & 23.80 & $\begin{array}{c}294 \\
2\end{array}$ \\
\hline
\end{tabular}

From the table above, the mean score of experimental class was (86.94) and control class was (81.72). It means that Task-Based Learning gives better result than Conventional Teaching. In other words, TaskBased Learning was more effective to be implemented in teaching speaking than Conventional Teaching. It can be caused by more speaking practices in Task-Based Learning. Then, it also provides students to discuss their opinions toward the task.

Furthermore, the normality and homogeneity testing also were tested. The normality testing was analyzed by Shapiro Wilk Test and the homogeneity test was analyzed by Test of Homogeneity Variance. Then, the hypothesis was tested by using t-test formula. The detail description can be seen on the following explanation.

\section{a. Normality Testing}

Normality testing was used to find out whether the data in experimental and control class are normally distributed or not. The data can be called normal if the significant value is bigger than significance alpha (0.05). After analysis, the significance value was 0.092 (Experiment) and 0.105 (Control). Those score indicated they were higher than 0.05 . It means that the data have normal distribution. The normality of data can be seen in the output below:

Table 2. Test of Normality

\begin{tabular}{|l|l|r|r|r|r|r|r|}
\hline & & \multicolumn{3}{|c|}{ Kolmogrov-Smirnov $^{\mathrm{a}}$} & \multicolumn{3}{c|}{ Shapiro-Wilk } \\
\cline { 2 - 8 } & Class & Statistic & \multicolumn{1}{|c|}{ df } & \multicolumn{1}{c|}{ Sig. } & \multicolumn{1}{c|}{ Statistic } & \multicolumn{1}{c|}{ df } & \multicolumn{1}{c|}{ Sig. } \\
\hline \multirow{2}{*}{ Score } & Experiment & .168 & $\mathbf{3 6}$ & .011 & .948 & $\mathbf{3 6}$ & .092 \\
\cline { 2 - 8 } & Control & .140 & $\mathbf{3 6}$ & .073 & .950 & $\mathbf{3 6}$ & .105 \\
\hline
\end{tabular}

\section{a. Lilliefors Significance Correction}

\section{b. Homogeneity Testing}

Homogeneity testing was used to find out whether the data in experimental and control class are homogeneous or not. The data can be called homogeneous if the significant value is higher than significance alpha
0.05. After analysis, the significance value was 0.069 in which this score was higher than significance alpha 0.05 . It means that the data are homogeneous. The homogeneity of data can be seen on the output below:

\begin{tabular}{|c|c|c|c|c|c|}
\hline & & Levene Statistic & Df1 & Df2 & Sig. \\
\hline \multirow[t]{4}{*}{ Score } & Based on Mean & 3.419 & 1 & 70 & .069 \\
\hline & Based on Median & 3.433 & 1 & 70 & .068 \\
\hline & $\begin{array}{l}\text { Based on Median and } \\
\text { with adjusted df }\end{array}$ & 3.433 & 1 & 66.476 & .068 \\
\hline & $\begin{array}{l}\text { Based on trimmed } \\
\text { mean }\end{array}$ & 3.543 & 1 & 70 & .064 \\
\hline
\end{tabular}

Table 3. Test of Homogeneity

Test of Homogeneity of Variance

c. Hypothesis Testing

In analyzing the hypothesis, Independent Sample $\mathrm{t}$-test was used. Ha is accepted if the value of $\mathrm{t}_{\text {observed }}$ is higher than $\mathrm{t}_{\text {table }}$ and $\mathrm{Ha}$ is rejected if the value of $\mathrm{t}_{\text {observed }}$ is lower than $t_{\text {table. }}$. The hypothesis are : 
H0 : Task-Based Learning does not give more significant influence on students' speaking skill than Conventional teaching

$\mathrm{Ha}$ : Task-Based Learning gives more significant influence on students' speaking skill than Conventional teaching

After analysis, the mean score of students' speaking skill in experimental was 86.94 which was higher than control class which the mean score was 81.72 . Then, the tobserved was 5.270 which was higher than ttable that was 1.669. The statistical analysis speaking data in experiment and control class are as follow :

Table 4. T-test Analysis of Speaking Data in Experiment and Control Class

\begin{tabular}{|l|l|l|l|l|l|}
\hline Class & $\mathbf{N}$ & Mean & SD & $\mathbf{t}_{\text {observed }}$ & $\mathbf{t}_{\text {table }}$ \\
\hline Experiment & 36 & 86.94 & 3.39 & 5.270 & 1.669 \\
\cline { 1 - 4 } Control & 36 & 81.72 & 4.87 & & \\
\hline
\end{tabular}

The table above shows that the alternative hypothesis (Ha) is accepted and the null hypothesis ( $\mathrm{H} 0)$ is rejected. It can be seen from the value of $t_{\text {observed }}$ is 5.270 which was higher than the value of $t_{\text {table }} 1.669$. Thus, the students who were treated by using Task-Based Learning had better speaking than those who were taught by using Conventional Teaching.

Dealing with this result, there are some possible reasons why Task-Based Learning could influence speaking. Prabhu (1987 :1) states that Task-Based Learning is a method that emphasizes communicative activity through task accomplishment. The students are asked to use English while accomplishing the task. Therefore, this provides speaking for students in the classroom.

Furthermore, Ellis (2003 :69) states that TaskBased Learning influence speaking skill since it provides negotiation of meaning, communicative strategies and communicative effectiveness. In TBLT, the students negotiate their opinions, thoughts or feelings through the task accomplishment. This process indirectly influences the students to have high motivation, self confidence and less anxiety to speak by using the target language. Then, through the task accomplishment, the students can arrange their communicative strategies by identifying what things that will be presented in speaking performance. This is commonly called as rehearsal activity where the students can plan and rehearse what they want to present in the report stage. They had opportunity to listen the others' opinion in order to get referential knowledge before they present it in front of the class. Because of this rehearsal activity, the students can get the communicative effectiveness where the students have more preparation to report their task through spoken language.

On the other side, the use of authentic or real world task also become the cause of speaking improvement. The use of real world or authentic task can motivate students to learn (Richards and Rodgers, 2001 :229). The students are likely more motivated if the tasks are related to their real world. Also, the use of communicative tasks that involve partnership and collaboration can engage students to speak by using target language.

There are some studies that had been conducted by some researchers related to task and speaking improvement. Mostly, the previous research found that the use of task on learning could give impact on speaking improvement. Wahidin $(2016: 149)$ found that Task-Based Learning gives impact toward speaking skill. The pre-task activities could improve the students' awareness toward the topic that would be discussed. It can help the students in getting background knowledge before speaking. The pair or group activity in task cycle also gave chance for them to decrease their communicative pressure, at least it increase their accuracy and fluency.

Next, Albino (2017:8) found that Task-Based Learning could increase fluency, grammar, utterances and interactional language on transactional conversation. During teaching process, the students were engaged to speak because the task promoted meaning making and focused on linguistic forms that use recasts as the corrective feedback. Then, the students might be more fluent in speaking because the tasks were related to their real life situation. Thus, the tasks that are communicative and authentic could influence the students' speaking improvement.

In current research, Anjum, et.al (2019:289) investigated that Task-Based Learning could help students to be active in classroom activities. The students get speaking improvement in term of fluency, pronunciation, vocabulary, communication skills and speech pattern. Then, it also helped the students to practice English speaking skill with less anxiety.

From the explanation above, it indicated that Task-Based Learning influences speaking. Through task activities, the students have chance to practice speaking skill within their group. Then, they can do negotiation of meaning in determining the best opinions toward topic discussion. They also can do rehearsal activity where it can train them to express arguments, ideas and feelings through spoken language.

Based on the result of this research, it can be implied that Task-Based Learning can enhance the students' competence on speaking. Task-Based Learning provides large opportunity to speak maximally through the task accomplishment. The task-based activities such as; negotiation of meaning and rehearsal activity could help the students to be more motivated in speaking without having high anxiety. Then, the use of real world tasks also could motivate the students to accomplish the task and it influenced the students to present their best in report stage.

Finally, this research is limited only to two texts; historical recount and narrative texts. So, the result of this research is limited only on these two texts. Thus, for the next researcher, it is good to do the research to investigate the infuence of Task-Based Learning towards other genre of texts in order to enrich the result of the research. 


\section{CONCLUSIONS}

In conclusion, Task-Based Learning gives significant influence in enhancing speaking skill of senior high school students. TBL provides opportunity for students to practice speaking through the task accomplishment. In accomplishing task, the students are suggested to use English in doing, planning report and presenting the task. Through task-based activities, the students can practice their English in classroom, therefore it can improve their speaking skill It emphasizes a meaning making process rather than grammatical focused learning. This means the students are free to speak without much grammatical correction therefore it can enhance their fluency in speaking. Also, the use of real world task in TBL can activate students' motivation to speak using target language. The motivated students have high effort to improve their speaking skill, automatically it also develop their speaking. Thus, learning based on task is effective to enhance speaking.

\section{ACKNOWLEDGMENTS}

Great thanks to my advisors, Prof. Dra. Yenni Rozimela, M.Ed., Ph.D and Dr. Ratmanida, M.Ed., TEFL who have helped me in writing this research, given a large time for further and deep discussion and offered critical comments that improved the quality of this research.

\section{REFERENCES}

[1] Albino, G. (2017). Improving Speaking Fluency in a Task-Based Language Teaching Approach : The Case of EFL Learners at PUNIV-Cazenga. SAGE Open, 1-1

[2] Aleksandrzak, M. (2011). Problems and Challenges in Teaching and Learning Speaking at Advanced Level. Uniwersytet im Adama Mickiewicza w Poznaniu, 37-48

[3] Anjum, M.H, Muhammad, M.K, \& N.B. Jumani (2019). The Effect of Task-Based Language Learning (TBLL) on Developing Speaking Skills of Secondary School Learners in Pakistan. International Journal of Linguistics, Vol 9, No.2, 283-291

[4] Brown, H.D. (2001). Teaching by Principles An Interactive Approach to Language Pedagogy (Second Edition). California : Longman

[5] Brown, H.D. (2007). Principles of Language Learning and Teaching (Fifth Edition). New York : Pearson Education

[6] Cameron, D. (2001). Working with Spoken Discourse. Oxford: SAGE Publications, Ltd.

[7] Carolina, A. (2016). Improving 10th Graders' English Communicative Competence through the Implementation of the Task-Based Learning Approach. Profile Issues in Teacher's Professional Development, 18(2), 95-100
[8] Ellis, R. (2003). Task-Based Language Learning and Teaching. New York : Oxford University Press

[9] Malihah, N. (2010). The Effectiveness of Speaking Instruction through Task-Based Language Teaching. REGISTER. Vol 3, No 1,85101

[10] Mudra, H. (2016). Enhancing Students' Speaking Skill through Task-Based Language Teaching (TBLT) at English Tadris Department of STAIN Kerinci. Al-Ta'lim Journal , 23(1), 78-87

[11]Nunan, D. (2003). Practical English Language Teaching (First edition). New York : Mc. Graw Hill

[12] Nunan, D. (2004). Task-Based Language Teaching. New York : University Press

[13] Prabhu, N.S. (1987). Second Language Pedagogy. New York : Oxford University Press

[14] Richards, J.C. (2008). Teaching Listening and Speaking From Theory to Practice. New York : Cambridge University Press

[15]Richards, J.C \& Theodore, S.R. (2001). Approaches and Methods in Language Teaching (Second Edition). UK : Cambridge University Press

[16]Ur, P. (1996). A Course in Language Teaching : Practice and Theory. New York : Cambridge University Press

[17] Wahidin, I. (2016). Task-Based Language Teaching in Developing Marine and Fisheris Students' Speaking Skill. ELT Worldwide, Vol. 3, No.2, 140-155

[18] Willis, J. (1996). A Framework for Task-Based Learning. Edinburgh : Addison Wesley Longman Limited.

[19] Willis, D. \& Jane, W. (2007). Doing Task-Based Teaching. New York: Oxford University Press.

[20]Zhou, Y. (2016). Applying Task-Based Language Teaching in Introductory-level Mandarin Language Classes at the College of the Bahamas. The International Journal of Bahamian Studies, $22,34-42$ 